\title{
COMPARISON OF THE FATTY ACID COMPOSITION OF LIPIS: FROM DIFFERENT ANIMAL TISSUES INCLUDING SOME TUMOURS*
}

\author{
J. H. VEERKAMP, I. MULDER AND L. L. $N$ "AN DEENEN \\ Iaboratory of Organic Chemistry, State University of Utrecht (The Netherlands)
}

(Received July 14th, 1961)

\section{SUMMARY}

With the aid of gas-liquid chromatography comparative fatty acid analyses have been made in lipid fractions of a number of mammalian tissues. Neutral lipid fractions seemed to possess animal specificity, i.e., their fatty acid patterns differed from animal to animal, but resembled one another for different tissues of one animal. On the other hand, phosphatides showed some tissue specificity, since their fatty acid patterns differed within one animal but showed similarity in homologue tissues (including tumours) of different animals. Fatty acid compositions of phosphatide fractions and of lipids from mitochondrial membrane preparations from the same tissue showed great similarity. Cell fractions did not differ in the fatty acid patterns of their lipid fractions from those of the whole tissue.

\section{INTRODUCTION}

It is generally accepted that membranes play an important part in regulating various biological and biochemical processes. Through variations in structure or chemical composition membranes may attain differences in properties, characteristic for a certain organ or animal. One important group of membrane constituents are the lipids, and among these, phosphatides play a central role in all membrane models ${ }^{1-3}$. Variations in phosphatide composition could be brought about by alterations in the polar part of their molecules, resulting e.g. in differences in lecithin or cephalin content. Many more differences may occur by variations in the fatty acid composition of the membrane phosphatides. In an earlier study ${ }^{4}$ we actually found a parallel between the permeability properties of a number of mammalian erythrocyres as determined by JACOBS $e t$ al..$^{5}$ and the amount of certain fatty acids obtained by alkaline hydrolysis of the membrane lipids.

Mostly it is difficult to isolate membrane lipids from the tissues without contamination with other lipids. We suppose, however, that determination of the fatty acid composition of the phosphatide fraction of the isolated lipids may be an approach for the understanding of the fatty acid composition of membranes in the tissues concerned.

In this paper a comparative study is made of the fatty acids of lipid fractions

"Communication No. $2 \mathrm{I}$ in the series Metabolism and Function of Phosphatides. See for preceding communications refs. 4, 6 and $r_{3}$. 
isolated from different tissues of mouse, rat, rabbit, pig, horse, ox and sheep, including some experimental tumours.

\section{METHODS}

The animals studied were grown up in the laboratory (mouse, rat and rabbit) or their tissues were obtained from the slaughter house (pig, horse, ox and sheep). The diets of the laboratory animals varied and were given ad libitum. Only the rats obtained a controlled diet ${ }^{*}$, containing $6 \%$ of lipids, with the following fatty acid composition: lauric acid, I\%; myristic, I.5\%; palmitic, $16 \%$; palmitoleic, $1.5 \%$; stearic, $2.5 \%$; oleic, $23 \%$; linoleic, $5 \mathrm{r} \%$ and linolenic, $3.5 \%$.

Tumours were obtained as described earlier ${ }^{6}$. Beside the benzopyrene tumour of the rat, the Brown-Pearce tumour of the rabbit and the Ehrlich ascites tumour cells of the mouse, hepatomas were grown in normal white rats by supplying their diets with $0.06 \%$ of $p$-dimethylamino azobenzene. Tumours appeared after 8-12 months. The non-necrotic parts of the tumours were isolated.

Cell fractions of tumours or normal tissues were obtained by means of centrifuging according to HuLTIN's ${ }^{7}$ modification of the procedure of SCHNEIDER AND HOGEBOOM ${ }^{8}$ after preparing homogenates in isotonic sucrose solution in a Potter-Elvehjem homogenizer. The three fractions isolated contained most of the nuclear material, of the mitochondria and of the microsomes (supernatant fraction) respectively. Fractions were checked by determinations of succinate dehydrogenase activity ${ }^{9}$.

Mitochondrial fragments were made from mitochondria by means of extractions with sodium chloride solutions according to the method of DALLAM ${ }^{10}$, resulting in a membrane-like material ${ }^{*}$.

Extraction of the lipids from fresh, normal or tumour tissues withdrawn from the animals shortly after killing them, was carried out with chloroform and methanol in a Waring Blendor according to BLIGH AND DYER ${ }^{11}$. Cell fractions and mitochondrial fragments were extracted in a similar way, the supernatant fraction after being concentrated by precipitating with trichloroacetic acid. The lipids were separated by chĩumatography on a silica column according to BORGSTRÖM ${ }^{12}$ (see also VEERKAMP et al. ${ }^{13}$ ). The neutral lipids were eluted with chloroform and the phosphatides with dry methano'. In the two fractions obtained $90 \%$ or more of the total lipid was $r$ covered $* \star *$. Ti.e phosphorus cortent of the isolated neutral lipid fractions did not exceed $0.05 \%$ whereas the phosphorus content of the phosphatide fractions from the various tissues ranged from $3.6 \%$ to $3.9 \%$. The phosphatides were sometimes separated in turn into choline-containing and non-choline-containing compounds by chromatography on an alumina column as described by RHODES AND LEA ${ }^{15}$. In handling the solutions and evaporating the solvents nitrogen was used to prevent the lipids from oxidation.

Methyl esters of the constituent fatty acids were obtained from the lipids by saponification with alcoholic $\mathrm{NaOH}$ under nitrogen and by treating the liberated fatty acids with a diazomethane solution (see for details KöGL et al. ${ }^{4}$ ).

\footnotetext{
" "U.T.-rattenvoer" from U. Twijnstra's Oliefabrieken, Maarssen (The Netherlands).

* Although there is no proof as yet of these salt-extracted mitochondria being membranes, DAllam shows that his preparations contain much of the membranous material and have lost much of the other material of the original mitochondria. We tested our preparations by determining the succinate dehydrogenase activity ${ }^{\circ}$, which was about $60 \%$ of that from the complete mitochondria.

** Analyses of lipils brfore and after silica chromatography showed that the used technique did not affect the fatty acid compositions (see Table 1 and ref. 14).
} 
Gas-chromatographic separation of the methyl esters was performed as before. The use of the two columns (with silicone grease and with polydiethyleneglycol succinate respectively as the station ry phases) facilitated the identification of the esters. The detector was a thermistor katharometer and He was used as the carrier gas. For each ester the peak area was calculated as percentage of the total of measured peak areas on the gas chromatogram and the obtained figure was taken for the weight percentage of the methyl ester in the sample.

The saponification and gas-chromatographic quantitation methods were checked as before ${ }^{4}$ by analysing standard mixtures of fatty acids. Furthermore, analyses of pure synthetic phosphatides prepared in our laboratory ${ }^{16,17}$ showed the methods to be correct, also for small samples.

\section{RESULTS}

The experimental results are compiled in the Tables I-IV. In most samples we found laurate, myristate, palmitate, palmitoleate, stearate, oleate, linoleate, linolenate, and arachidonate. Trace amounts of other acids, among which arachidate was found most frequently, have been neglected. As a rule chromatograms were stopped on the polydiethyleneglycol succinate column after the appearance of the arachidonate peak, and on the silicone grease column after the appearance of arachidate. Sometimes the occurrence of esters with a longer retention time was searched for. In most cases these esters were absent, but e.g. in rat-liver phosphatides some five percent of a docosahexaenoate was found, identified by means of theretention times or: the two columns.

TABLE I

FATTY ACID COMPOSITION OF NEUTRAL LIPID FRACTIONS

Weight percentages of fatty acid methyl esters found. The number of analyses and the total number of animals are placed between parentneses in that order. With the rat also figures for depot fat are given.

\begin{tabular}{|c|c|c|c|c|c|c|c|c|c|c|}
\hline Animal & Tissue & & $\begin{array}{l}\text { Lawrate + } \\
\text { myristate }\end{array}$ & Palmitate & $\begin{array}{c}\text { Palmit- } \\
\text { oleate }\end{array}$ & Stearate & Oleate & Linoleate & $\begin{array}{l}\text { Lino- } \\
\text { lenate }\end{array}$ & $\begin{array}{c}\text { Arachid- } \\
\text { onate }\end{array}$ \\
\hline \multirow[t]{5}{*}{ Mouse } & Liver & $(2 ; 67)$ & 0.5 & $24 \cdot 5$ & $5 \cdot 5$ & 4 & $44 \cdot 5$ & 19.5 & 0.5 & $\mathbf{I}$ \\
\hline & Kidney & $(2 ; 67)$ & 3 & 27 & 8.5 & 6 & $4^{I}$ & 14 & 0.5 & 一 \\
\hline & Lung & $(2 ; 67)$ & 3 & 30 & 9 & 7 & 41.5 & 9 & 0.5 & - \\
\hline & Ascites tur & lour & & & & & & & & \\
\hline & cells & $(4 ; 190)$ & I. 5 & 19.5 & $3 \cdot 5$ & I I & 40 & 18 & 3 & $3 \cdot 5$ \\
\hline \multirow[t]{7}{*}{ Rat } & Depot fat & $(2 ; 4)$ & 4 & 27 & 10 & 4 & 35.5 & 18.5 & $\mathbf{I}$ & - \\
\hline & Liver & $(5 ; 64)$ & 2 & 30 & $5 \cdot 5$ & 3 & 32 & 24 & 1.5 & 2 \\
\hline & Kidney & $\left(3 ; 4^{8}\right)$ & 2.5 & 29.5 & 9.5 & 7 & 33 & I5.5 & 2 & $\mathbf{I}$ \\
\hline & Lung & $\left(3 ; 4^{8}\right)$ & 4 & 30.5 & 10 & $5 \cdot 5$ & $33 \cdot 5$ & $14 \cdot 5$ & J. 5 & 0.5 \\
\hline & Benzopyrer & & & & & & & & & \\
\hline & tumour & $(6 ; 60)$ & 4 & 29 & 5 & $9 \cdot 5$ & 34 & I 5 & I. 5 & 2 \\
\hline & Hepatoma & $(4 ; 8)$ & 2 & 25 & 6 & 8.5 & 37 & I4 & 1 & 6.5 \\
\hline \multirow[t]{8}{*}{ Rabbit } & Liver & $(3 ; 11)$ & 4 & 39 & I I & 4 & 30.5 & 8.5 & 2.5 & 0.5 \\
\hline & Kidney & $(2 ; 6)$ & 4.5 & 37 & I I & $3 \cdot 5$ & 25.5 & I3 & 4.5 & I \\
\hline & Lung & $(2 ; 8)$ & 5 & 39 & 9.5 & 6 & 25 & I2 & 3 & $0 . \vec{j}$ \\
\hline & Brain & $(2 ; 7)$ & 4 & 33 & 6.5 & 18 & 23.5 & 9.5 & 3 & 2.5 \\
\hline & Heart & $(2 ; 6)$ & 45 & $37 \cdot 5$ & 7 & $4 \cdot 5$ & 28.5 & I 4 & 2.5 & I. 5 \\
\hline & Spleen & $(1 ; 3)$ & 7.5 & 41.5 & 10.5 & 3 & 26.5 & 9 & 2 & - \\
\hline & Brown-Pea & & & & & & & & & \\
\hline & tumour & $(4 ; 5)$ & $5 \cdot 5$ & $35 \cdot 5$ & 7 & 6.5 & 29.5 & $\mathbf{1 3}$ & 3 & + \\
\hline
\end{tabular}




\section{TABLE II}

FATTY ACID COMPOSITION OF PHOSPHATIDES

Weight percentages of fatty acid methyl esters found. The number of analyses and the total number of animals are placed between parentheses in that order.

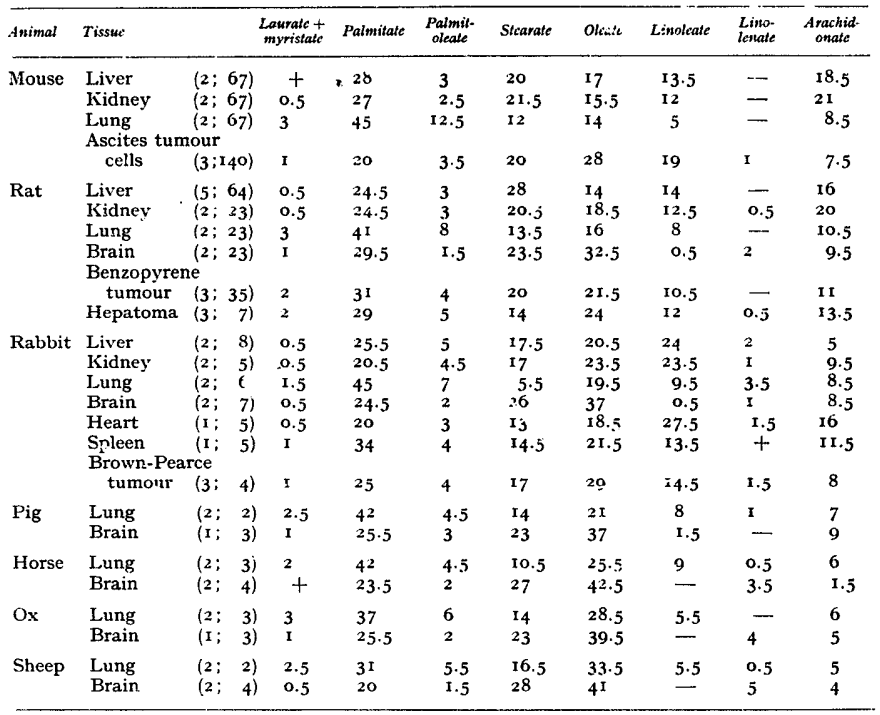

TABLE III

CILL FRACTIONS

Weight percentages of fatty acid methyl esters found in neutral lipids and in phosphatides respectively.

\begin{tabular}{|c|c|c|c|c|c|c|c|c|c|c|}
\hline Tissue & $\underset{\text { fraction }}{\text { Lipid }}$ & Cell fraction & $\underset{\text { myristate }}{\text { Laurate }}+$ & Palmitale & $\begin{array}{l}\text { Palmit- } \\
\text { olcale }\end{array}$ & Stearale & Oleate & Linoleate & $\begin{array}{l}\text { Lino- } \\
\text { ienate }\end{array}$ & $\underset{\text { onale }}{\text { Arachid. }}$ \\
\hline \multirow{6}{*}{$\begin{array}{l}\text { Liver } \\
\text { of } \\
\text { rat } \\
\text { (10 } \\
\text { ani- } \\
\text { mals) }\end{array}$} & Neutral & Nuclei & 2 & 29.5 & 6 & I.5 & $3 I$ & 26 & $\mathbf{I}$ & 3 \\
\hline & lipids & Mitochondria & $\mathbf{r}$ & 32 & 5 & 2 & 36 & 22 & + & 2 \\
\hline & & Supernatant & 1.5 & 29.5 & 6 & 2 & 34 & $24 \cdot 5$ & I & 1.5 \\
\hline & Phos- & Nuclei & I. 5 & 225 & 2.5 & 26.5 & II. 5 & 17 & 0.5 & 18 \\
\hline & pha- & Mitochondria & 1.5 & 21.5 & 2.5 & 24 & 13.5 & 20 & 0.5 & I6.5 \\
\hline & tides & Supernatant & + & 26 & 5 & 18.5 & 16.5 & 21 & - & 13 \\
\hline \multirow{6}{*}{$\begin{array}{l}\mathrm{He}- \\
\text { pato- } \\
\text { ma } \\
\text { of rat } \\
\text { (3 } \\
\text { ani- } \\
\text { mals) }\end{array}$} & Neutral & Nuclei & I & 30.5 & 8 & 13 & 37.5 & to & $-\infty$ & - \\
\hline & lipids & Mitochondria & I. 5 & 28 & $4 \cdot 5$ & $7 \cdot 5$ & 44 & 12 & $\mathrm{I}$ & 1.5 \\
\hline & & Supernatant & $3 \cdot 5$ & 28 & 6 & 9.5 & 40 & 10.5 & + & 2.5 \\
\hline & Phos- & Nuclei & 3 & 28 & 6.5 & Io & $3 \mathrm{I} .5$ & $I_{4}$ & + & 7 \\
\hline & pha- & Mitochondria & 2.5 & 25 & $6^{\circ}$ & $x_{4}$ & 29 & 15.5 & + & 8 \\
\hline & ) iudes & Supernatant & 2.5 & 28.5 & 5 & 13.5 & 31.5 & 13 & + & 6 \\
\hline
\end{tabular}


TABLE IV

MEMBRANE FRAGMENTS OF MITOCHONDRIA

Weight percentages of fatty acid methyl esters obtained from the extracted total lipid. The number of analyses and the total number of animals are placed between parenthesrs in that order.

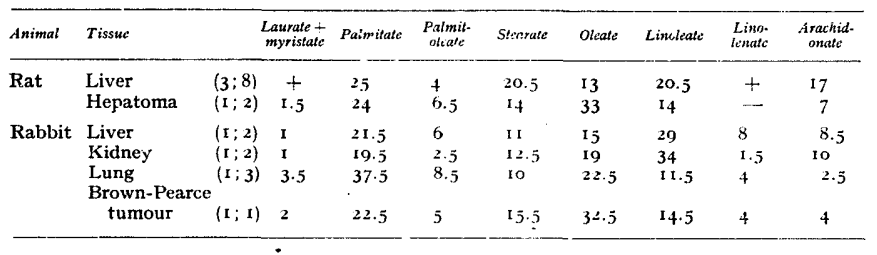

TABLE V

FATTY ACID ANALYSES HEFORE AND AFTER SILICA COLUMN CHROMATOGKAPHY OF THE LIPIDS

The fatty acid composition determined directly in total iipids extracted from rat liver is compared with the total fatty acid composition calculated from the analyses of the corresponding neutral and phosphaside fractions, taking into accownt that the total lipids of rat liver are composed of $22 \%$ of neutral lipids and $78 \%$ of phosphaticies (mean of 9 separate determinations (cf. ref. 14)). Weight percentage's are given of the fatty acid methyl esters. The number of analyses and the total number of animals are placed between perentheses in that order.

\begin{tabular}{|c|c|c|c|c|c|c|c|c|c|}
\hline Lipid fration & & $\begin{array}{l}\text { Laurate + } \\
\text { myristate }\end{array}$ & Palmitate & $\begin{array}{l}\text { Palmit- } \\
\text { vitcalc }\end{array}$ & Stearate & Oleate & Linoleate & $\begin{array}{l}\text { Lino- } \\
\text { lenate }\end{array}$ & $\begin{array}{c}\text { Arachid- } \\
\text { ossate }\end{array}$ \\
\hline \multirow{4}{*}{$\begin{array}{l}\text { a. Neutral lipids } \\
\text { b. Phosphatides } \\
\text { c. Total lipid, } \\
\text { direct analysis } \\
\text { d. Totai lipid, calcul } \\
\text { from a and b }\end{array}$} & $(5 ; 64)$ & 2 & 30 & $5 \cdot 5$ & 3 & 32 & 24 & I. 5 & 2 \\
\hline & $(5 ; 64)$ & 0.5 & $24 \cdot 5$ & 3 & 28 & 14 & 14 & - & 16 \\
\hline & $\begin{array}{l}(3 ; 46) \\
\text { tted }\end{array}$ & 0.5 & 25.5 & 2.5 & 22 & 18 & I 6.5 & + & I5 \\
\hline & & $\mathbf{I}$ & 25.5 & $3 \cdot 5$ & 22.5 & 18 & 16 & 0.5 & I3 \\
\hline
\end{tabular}

Additional confirmation of the identity was obtained by chromatography after hydrogenation with the aid of platinum catalyst. Also KLENK AND OETTE ${ }^{18}$ identified this fatty acid in rat-liver phosphatides. The occurrence of this or other higher unsaturated fatty acids in some of our samples may not be excluded.

Nearly each figure in the tables was determined by calculating the niean of the results of at least two separate analyses of tissue samples of different individuals or groups of individuals. Differences between two such anaiyses were greater than differences between duplicate analyses of one tissue sample. An impression of the variability in the fatty acid spectrum of the lipid fractions from one animal tissue is given by Table VI, where a comparison is possible of five sepirate analyses of the fatty acid composition of the neutral lipid fraction and also of the phosphatides isolated from rat liver. Although it is known that age, season, diet etc. may influence to some extent fatty acid compositions in animals, from these results and from comparable other series of analyses we concluded that each studied fraction had a rather constant and often characteristic mean fatty acid pattern, which was suitable for a comparative study.

Direct fatty acid analysis of total lipids from rat liver compares very weil with the composition calculated from analyses of the two lipid fractions, as can be seen 


\section{TABLE VI}

VARIABILITY OF THE FATTY ACID COMPOSITION OF (A) THE NEUTRAL LIPID FRACTION AND OF (B) THE PHOSPHATIDES ISOLATED FROM RAT LIVER

Weight percentages are given of the methyl esters, calculated as the percentage of the peak area from the sum of peak areas on the chromatogram. The averages and the standard errors of the averages are added.

Expt. $\begin{gathered}\text { Number of } \\ \text { animals }\end{gathered} \begin{gathered}\text { Laurate } \\ \text { myristate }\end{gathered}$ Palmitate Palmitoleate Stcarate Oleate Linoleate Linolenate Arachidonate

\begin{tabular}{|c|c|c|c|c|c|c|c|c|c|}
\hline \multicolumn{10}{|c|}{ (A) Netutral Lipid } \\
\hline I & 25 & 2.5 & 29 & 7 & 4 & 27 & 26 & 0.5 & 3 \\
\hline 2 & II & I & 31 & 5.5 & 2 & 33.5 & 23 & I & 3 \\
\hline 3 & 6 & 2 & 28.5 & 6.5 & $4 \cdot 5$ & 34 & $2 I$ & 2 & I. 5 \\
\hline 4 & Io & 2 & 31 & 4 & 2 & 35 & 23.5 & I & 1.5 \\
\hline \multirow[t]{2}{*}{5} & I2 & I & 30.5 & $5 \cdot 5$ & 3 & $31 \cdot 5$ & 26.5 & 2 & - \\
\hline & Average: & $2 \pm 0.5$ & $30 \pm I$ & $\begin{array}{l}5.5 \pm 1 \\
\text { (B) Phos }\end{array}$ & $\begin{array}{c}3 \pm \mathbf{1} \\
\text { phatides }\end{array}$ & $32 \pm 1.5$ & $24 \pm 1.5$ & $1.5 \pm 0.5$ & $2 \pm \mathbf{I}$ \\
\hline I & 25 & I. 5 & 27 & 3 & 28.5 & 16 & 12.5 & - & \multirow{2}{*}{$\begin{array}{l}\text { II.5 } \\
26\end{array}$} \\
\hline 2 & II & $I$ & 19.5 & 2.5 & 29.5 & 11 & 10.5 & $\rightarrow$ & \\
\hline 3 & 6 & + & 25.5 & 2.5 & $3 I$ & 14.5 & 13.5 & - & 13 \\
\hline 4 & 10 & + & 26 & 4 & 26 & $I_{, j}$ & 18 & + & II \\
\hline \multirow[t]{2}{*}{5} & 12 & 1.5 & 25 & 2 & $24 \cdot 5$ & 12.5 & 16 & - & 18.5 \\
\hline & Average: & $0.5 \pm 0.5$ & $24.5 \pm 1.5$ & $3 \pm 0.5$ & $28 \pm 1.5$ & $14 \pm 1$ & $14 \pm 1.5$ & - & $16 \pm 3$ \\
\hline
\end{tabular}

from the data presented in Table $V$. As with other lipids the same favourable results were obtained, it appeared that the used methods for separating the lipids, including siiica chromatography, did not affect the fatty acid analyses of the resulting fractions.

To facilitate a ready comparison of the results, the data of the Tables I-IV are rearranged to give the Figs. I-5. Fig. 6 shows earlier results ${ }^{4}$.

In Fig. I a comparison is made of analyses of the neutral lipid and phosphatide fractions respectively, obtained from liver, kidney, lung and tur:1ours of mouse, rat and rabbit, including three other tissues of the rabbit. The neutral lipids from different tissues of one animal show a remarkable similarity in their fatty acid patterns, whereas with the corresponding phosphatide fractions no such characteristic pattern emerges.

In Fig. 2 phosphatides of homologous tissues of different animals are compared as regards their fatty acid composition. Marked resemblance is shown by the phosphatides from the lung of the seven studied animals and no less so by those from the brain of the six studied ones. Although also liver and kidney respectively of mouse, rat and rabbit show some similarity in their phosphatide fatty acids, this similarity is a little less conspicaous. Remarkable again are the analyses of phosphatides from the four different tumours investigated. Ehrlich ascites cells from the mouse, benzopyrene tumour and hepatoma from the rat, and Brown-Pearce tumour from the rabbit all show some similarity in the fatty acid composition of their phosphatides.

Cell fractions prepared from liver and hepatoma of the rat before extracting the lipids are compared in Fig. 3. Hardly any differences exist between the fatty acid compositions of nuclei, mitochondria and supernatant fractions of one tissue, neither in the neutrai lipids nor in the phosphatides.

Perhaps Fig. 4 throws light upon the question whether the studied phosphatide 


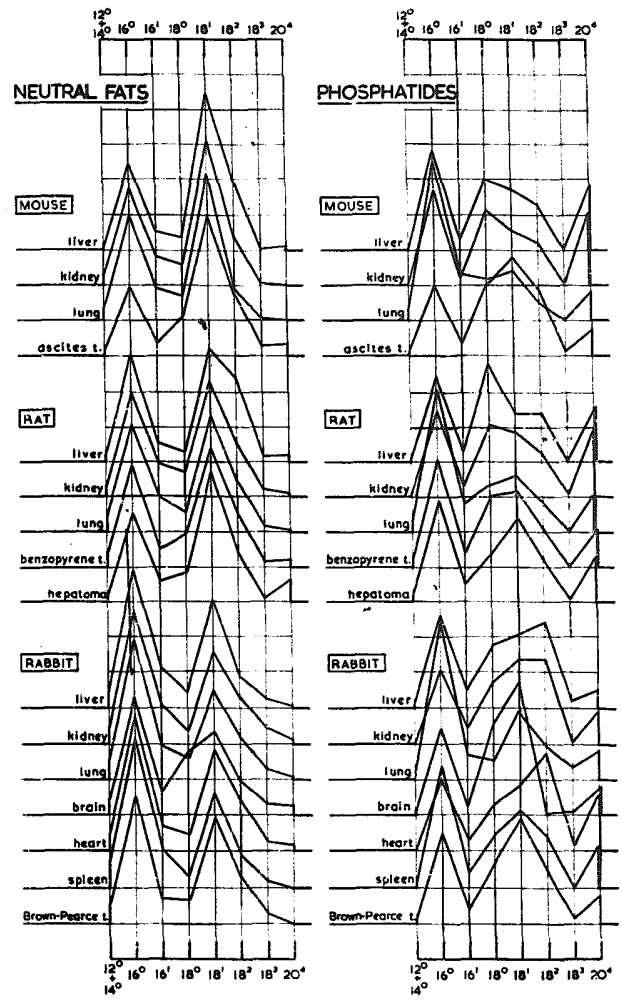

Fig. I. Fatty acid compositions of neutral lipids and of the phosphatide fraction of lipids from tissues of three animal species. On the abscissa the fatty acids are indicated by means of the number of carbon atoms and the number of double bonds; e.g. $18^{2}$ stands for octadecadienoic acid, i.e. linoleic acid. On the ordinate weight percentages of fatty acid methyl esters are plotted. The distance between two horizontal lines corresponds with 10\% of fattv acid.

fractions might be representative for membrane phosphatides. As can be seen, in the studied cases the fatty acid patterns of the phosphatides isolated from the whole tissue resemble rather the fatty acid patterns of the isolated mitochondrial membranous fragments of the corresponding tissue. 


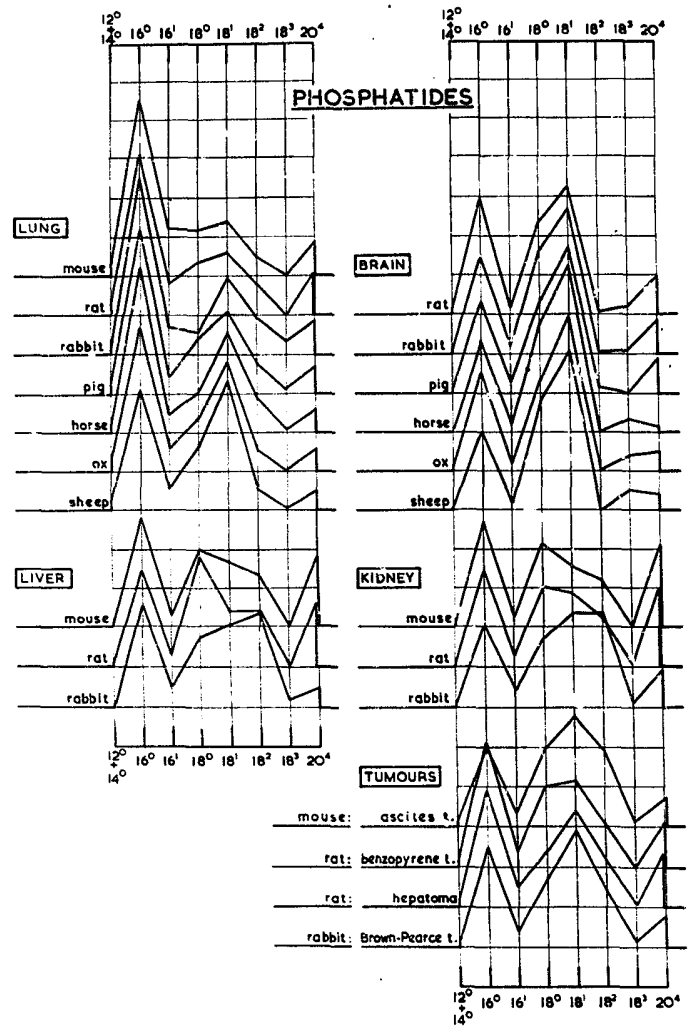

Fig. 2. Fatty acid compositions of phosphatides from four normal tissues and from some tumours. Explanations see Fig. 1 .

\section{DISCUSSION}

Already a good many data are known even in the older literature about fatty acid compositions of different lipid fractions ${ }^{10}$, or especially of phosphatides ${ }^{20}$. The modern method of gas-chromatographic analysis allowed us to obtain in a relatively simple way a number of data also from small lipid samples, which did not suffer from scattering caused by different experimental errors. Though we are aware that additional analyses of different tissues of many more animals should be necessary to 

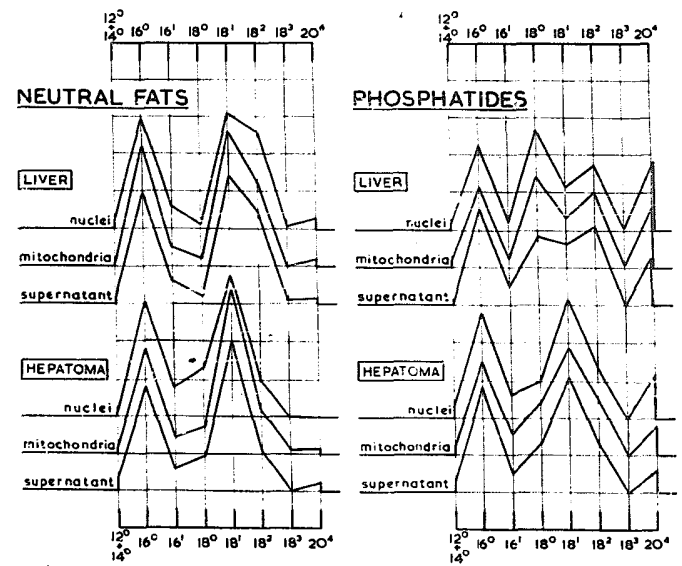

Fig. 3. Fatty acid ccmposition of neutral lip.ds and of the phosphatide fraction of lipids from the three cell fractions isolated from rat liver and from rat hepatoma respectively. Explanations sce Fig. I.

allow definite conclusions, some general remarks may be made on the grounds of the present results.

As is shown, the neutral lipid fractions seem to possess animal specificity with respect to their fatty acid composition (see Fig. I). In the rat the fatty acid compositions of neutral lipid fractions resemble rathei that of the abdominal depot fat (Fig. 5). Furthermore, the fatty acid compositions of neutral lipids differ greatly from those of lipids extracted from mitochondrial membranous fractions ( $c f$. Figs. $I$ and 4). Apart from the marked differences between neatral lipid compositions of different animals (cf. the palmitate-oleate proportion) there is some resemblance in mouse, rat and rabbit, c.g. the low stearate and arachidonate content.

Contrary to the neutral lipids, the phosphatides show a certain tissue-specific fatty acid composition (see Fig. 2). The lipids from salt-extracted mitochondria, which were shown to contain $80 \%$ of phosphatides ${ }^{14}$, resemble in their fatty acid compositions the phosphatides isolated from the whole tissues (Fig. 4). As these mitochondrial fragments contain much membranous material, the above observations are in agreement with the usual concept ${ }^{1-3}$ that the essential membrane lipids are the phosphatides. Furthermore, tentative conclusions about fatty acid compositions of membrane phosphatides drawn from analyses of phosphatides isolated from the whole tissue seem now to be justified.

Beside striking similarities between the fatty acid patterns of phosphatides from the same tissue of different animals, there are also differences. In the series mouse, rat, rabbit, pig, horse, ox, sheep, a gradual decrease occurs in the palmitate-oleate proportion not only in the lung phosphatides, but also in the brain phosphatides. In erythrocyte membranes a decrease in palmitate-oleate proportion was found in the same sequence of animals ${ }^{4}$. Here the differences were more pronouncod (Fig. 6) and 


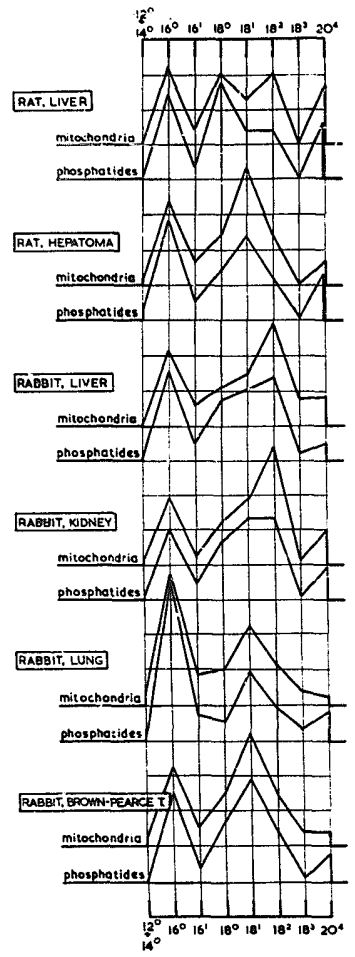

Fig. 4. Comparisun of fatty acid compositions of total lipids from mitochondrial membranous fragments with fatty acid compositions of the phosphatide fractions from the same whole tissues. Explanations see Fig. $x$.

Fig. 6. Fatty acid compositions of lipids from red blood cell membranes. Explanations see Fig. I.

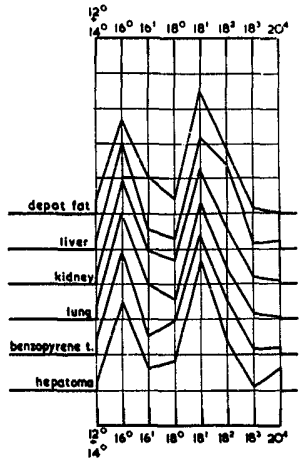

Fig. 5. Comparison of fatty acid composition of depot fat with fatty acid compositions of neutral lipids from the rat. Explanations see Fig. r.

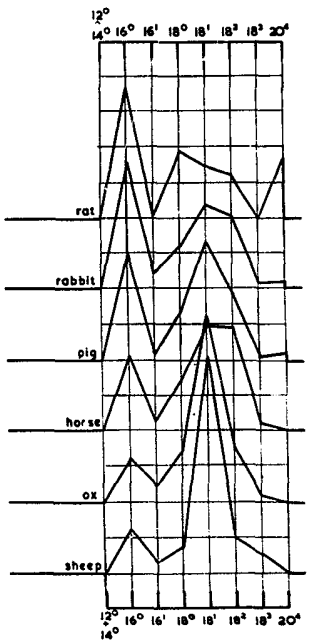

could be related to a gradual difference in permeability properties of the erythrocyte membranes $^{5}$ of the studied animals. Remarkable is the high amount of palmitate in all lung phosphatides, the absence of linoleate in the studied brain phosphatides and the high arachinodate percentage in liver and kidney phosphatides. Especiaily ini- 
triguing is the relatively high amount of oleate in the studied tumours. In rat hepatoma, when compared with normal rat liver, the oleate-stearate proportion in the phosphatides is even inverted. The physiological significance of these interesting phenomena is still obscure.

Remarkable was the similarity found between the fatty acid compositions of different cell particles of one tissue, a result also obtained by other authors ${ }^{\mathbf{2 1 - 2 3}}$. Differentiation between membranes of cell particles perhaps goes by other means than by variation of the fatty acid composition. Moreover, with quite the same constituents different structures can be built up in the various membranes. On the other hand, one may suppose that essential analytical differences only exist within the cell in situ, and that by splitting up the cell into fractions, together with breaking the coherence between the different membranes, the membrane lipids to some extent are pooled. Such a coherence has really been shown to exist by means of electron-microscopic studies ${ }^{24,25}$.

Finally the question arose whether the differences found in fatty acid composition could not be a reflection of the differences in the content of the various types of phosphatides. Fatty acid analyses of choline-containing and non-choline-containing phosphatide fractions indeed showed differences. In accordance with experiments of $\mathrm{GRAY}^{28}$ a relatively high amount of palmitate and a relatively low amount of stearate and of arachidonate were found in the choline-containing fractions ${ }^{14}$. However, the differences could not always account for the differences in fatty acid composition of the total phosphatides from the various tissues. It seems worthwhile to analyse the fatty acids after further separation of the phosphatides into well-characterized fractions, and to investigate the effects of diet and age.

\section{REFERENCES}

1 A. K. Parpart and R. Ballentine, in E. S. G. Barron, Modern Trends in Physiology and Biochemistry, Academic Press, Inc., New York, 1952, p. 135.

2 W. D. Stein and J. F. Danielli, Discussions Faraday Soc., 2 I (1956) 238.

3 H. L. Booij and H. G. Bungenberg de Jong, in L. V. Heilbronn and F. Weber, Protoplasmatologia, Handbuch der Protoplasmaforschung, Vol. I, No. 2, Springer Verlag, Vienna, 1956.

4 F. Kögl, J. de Gier, I. Mulder an d L. L. M. van Deenen, Biochim. Biophys. Acta, 43 (1960) 95.

5 M. H. Jacobs, H. N. Glassman and A. K. PARPart, J. Exptl. Zool., 113 (1950) 277.

- F. Kögl, C. Smak, J. H. Veerkamp and L. L. M. van Deenen, Z. Krebsforsch., 63 (1960) $55^{8}$.

7 T. Hultin, Exptl. Cell Research, I (1950) 376.

- W. C. Schneider and G. H. Hogeboom, J. Biol. Chem, i 83 (1950) 123.

- W. C. Schneider and V. R. Potter, J. Biol. Chem., I49 (I943) 2 I7.

10 R. D. Dallam, Arch. Biochem. Biophys., 77 (1958) 395.

11 E. G. Bligk and W. J. Dyer, Can. J. Biochem. and Physiol., 37 (1959) 911.

12 B. Borgström, Acta Physiol. Scand., 25 (1952) Ior.

13 J. H. Veerkamp, I. Mulder and L. L. M. van Deenen, Z. Krebsforsch., 64 (I96I) 137.

14 J. H. Veerkamp, Thesis, Utrecht, I960.

15 D. N. Rhodes AND C. H. Lea, Biochem. J., 65 (1957) 526.

10 F. Kögl, G. H. de Ha as and L. L. M. van Deenen, Rec. trav. chim., 79 (1960) 661.

17 G. H. de HaAs and L. L. M. van Deenen. Tetrahedron Letters, 9 (1960) $1 ; 22$ (1960) 7 .

18 E. KLeNK AND K. OetTe, $Z$. physiol. Chem. Hoppe-Seyler's, 318 (1960) 86.

10 T. P. Huditch, The Chemical Constitution of Natural Fats, 3rd Ed., Chapman and Hall, Ltd., London, 1956.

so H. Wirtcoff, The Phosphatides, Reinhold Publishing Corp., New York, $195 \mathrm{I}$.

21 D. Charlot-Hatmovict, Arch. Sci. Physiol., 11 (1957) 169 and 185.

22 G. J. Marco, L. J. Macklin and R. S. Gordon, Federation Proc., r9 (r96o) 222.

22 M. G. MacFarlane, G. M. Gray and L. W. Wheeldon, Biochem. J., 77 (1960) 626.

24 G. E. PALAdE, J. Biophys. Biochem. Cytol, I (1955) 567 .

26 M. A. Epstein, J. Biophys. Biochem. Cytol., 3 (1957) $85 \mathrm{I}$.

s8 G. M. GRAY, Biochem. J., 77 (1960) 82 . 